\begin{tabular}{|c|l|}
\hline Title & A localized disaster-resilience index to assess coastal communities based on an analytic hierarchy process (A HP) \\
\hline Author(s) & Orencio, Pedcris M.; Fujii, Masahiko \\
\hline Citation & $\begin{array}{l}\text { International Journal of Disaster Risk Reduction, 3, 62-75 } \\
\text { https://doi.org/L0.1016/.ijdr.2012.11.006 }\end{array}$ \\
\hline Issue Date & 2013 03 \\
\hline Doc URL & http://hdl.handle.net/2115/52643 \\
\hline Type & article (author version) \\
\hline File Information & AHP-Disaster Resilience.pdf \\
\hline
\end{tabular}

Instructions for use 


\section{A LOCALIZED DISASTER-RESILIENCE INDEX TO ASSESS COASTAL COMMUNITIES BASED ON AN ANALYTICAL HIERARCHY PROCESS (AHP)}

Pedcris M. Orencio and Masahiko Fujii

Author's Notes

Corresponding Author:

Pedcris M. Orencio, PhD Student, Graduate School of Environmental Science, Hokkaido University, North 10 West 5 Sapporo Hokkaido Japan 060-0810

E-mail: p.orencio@ frontier.hokudai.ac.jp Laboratory Office Phone: (+81)11-706-3026

Masahiko Fujii, Associate Professor, Faculty of Environmental Earth Science, Hokkaido University, North 10 West 5 Sapporo Hokkaido Japan 060-0810

E-mail: mfujii@ees.hokudai.ac.jp Laboratory Office Phone/ Fax: (+81)11-706-2359 


\section{ABSTRACT}

2

The increased number of natural hazards due to climate variability has resulted in numerous disasters in developing countries. In the Philippines, these are expected to be more common in coastal areas. The common approach to mitigating disasters in this area is to enhance

6 the inherent capabilities of local communities to reduce the effects. Thus, this study proposed an 7 index for a disaster-resilient coastal community at the local level. The composites of the index 8 were determined through a process of prioritizing national-level components of a risk9 management and vulnerability-reduction system. The process followed a Delphi technique, 10 wherein 20 decision makers in Baler, Aurora, the Philippines identified criteria and elements that 11 can be used to reduce the vulnerability of coastal communities using paired comparisons for the 12 Analytic Hierarchy Process (AHP). The results showed that environmental and natural resource 13 management, sustainable livelihood, social protection, and planning regimes were very important 14 and represented $\geq 70 \%$ of the overall weights of criteria subjected to comparisons. These criteria 15 and their elements represented the local-level outcome indicators of the composite index for a 16 disaster-resilient coastal community, which was measured using a weighted linear combination 17 (WLC) approach to both outcome and process indicators. The index could be used by local 18 governments as a tool to facilitate meaningful disaster-risk reduction and management.

20 Keywords: Disaster-resilience index, resilience components, coastal communities, analytic 21 hierarchy process (AHP), Delphi technique 


\section{INTRODUCTION}

25

26

27

The number of people affected by disasters has increased considerably over the last 30 years. Droughts, floods, and tropical storms accounted for approximately 100 thousand fatalities and US $\$ 250$ billion of damage in $2005[1,2]$ and for $80 \%$ of life-threatening natural hazards worldwide [3]. Based on distribution, developing countries experienced the greatest impact and loss [4], accounting for $97 \%$ of the affected communities worldwide [5]. Because coastal zones within $200 \mathrm{~km}$ of the oceans are home to about half of the global population [6] and are more prone to hazards $[7,8]$, a large number of people are at risk. This population is often composed of communities that lack the capacity to effectively plan for and respond to hazards [9].

If vulnerable people and property are not considered, hazards can be regarded as simply natural environmental processes [10]. Based on this view, hazard-risk management and disaster solutions have shifted from the typical technical solutions provided by hard science toward understanding conditions associated with the human aspects of disaster occurrences [11]. This includes the application of systems that increase security through social and ecological resilience [12]. Likewise, factors that diminish the adverse hazard effects must be understood, as these may improve the capacity of a community to respond to and recover from subsequent hazard events [13]. By strengthening their local capacity, it is possible to develop invulnerable communities [14].

Resilient communities experience less damage and tend to recover quickly from disasters [15]. These communities absorb stress either through resistance or adaptation, manage and maintain basic functions despite effects, and can recover with specific behavioral strategies for risk reduction [16]. To determine and to measure the factors to enhancing resilience of coastal 
communities in the face of disasters, we performed a case study of local indicators of a disaster-

47 resilient coastal community in the Philippines.

\subsection{Disasters and local coping mechanisms in the Philippines}

The Philippines lie between the Pacific and Eurasian plates along the Western Pacific basin, a location frequented by climatic conditions such as typhoons, sea surges, and volcanic eruptions. According to the Center for Research on the Epidemiology of Disasters (CRED), the country was the most disaster-stricken nation in the world in 2009 [17], with a total of 191 natural and human-induced disasters reported to have killed 903 persons and affecting more than 2.8 million families [18].

Meanwhile, a huge gap between recognition and active implementation of disastermanagement programs exists in the Philippines, which is often attributed to the failure of the government to provide adequate resources, education, and awareness related to mitigating various hazard threats [19]. Destruction in different parts of the country had clearly manifested in poor disaster prediction and forecasting failures, especially in the local levels. Local capability to undertake risk mitigation is lacking and local governments rarely performed risk assessments

62 without external support [19,20]. Expected investments of funds in local risk-management 63 policies also posed a significant challenge in terms of political support, which often resulted in a 64 biased implementation and community participation in disaster-management programs [19,20]. Within these situations, disasters are caused not only by natural events but also by the

66 dysfunctional social institutions and inherently vulnerable nature of the community [11]. In the 67 coastal areas, for instance, where $60 \%$ of the Philippines' population resides, a large portion of 68 people and property must make adjustments when disasters occur [21], including many fishery- 
69 dependent communities that were constantly affected by poverty and a lack of social services $70[21,22]$.

71 Nonetheless, unique local mechanisms or indigenous response systems become typical in 72 some disaster-prone areas in the country [19,23]. An example of this is the flood-prone 73 communities in the municipality of Bula, Camarines Sur, which established management teams

74 and implemented systems for response and recovery from disasters [24]. Projects such as the 75 Citizen-Based and Development-Oriented Disaster Response (CBDODR) and Community-based 76 Disaster Risk Management (CBDRM), implemented by non-government organizations, have 77 added to this context, as they transformed at-risk communities into disaster-resilient 78 organizations [19].

79 NEDA et al. [20] has incorporated some activities of these projects in an approach that 80 mainstreamed disaster-risk reduction (DRR) to the sub-national level. A tool to assess the factors 81 that could enhance local resilience from disasters, however, would significantly contribute for a 82 localized DRR approach.

\subsection{Local-level disaster-risk reduction}

UNISDR [25] highly recognized the capacity of local communities as cornerstones to the

86 overall global movement for disaster-risk reduction. Practically, this means putting greater

87 emphasis on what people can do for themselves and how to strengthen their capacity for 88 resilience, rather than concentrating on their vulnerability to disaster or their needs in an emergency [16]. This concept recognizes that, by focusing on the capability and ability to adapt, 
In this paper, we adopted the term resilience from ecosystem resilience concepts [27]

92 within the ecological literature. This type of resilience occurs after a disturbance and is related to

93 the system's ability to adapt, reorganize, undergo change, and still maintain its basic structure,

94 function, identity and feedbacks [28]. The concept can be explained broadly as the capacity of a

95 community, a group or an organization exposed to a hazard to maintain functional level,

96 withstand loss or damage or to recover from the impact of a disaster and reorganize for future

97 protection [4].

Community resilience is increasingly being seen as a key step towards disaster risk

99 reduction, and the ability to measure it is largely considered by researchers [13]. How

100 researchers were viewing resilience, however, influenced the proposed measurements, for

101 instance, as a process in the ecological perspective [29] or as an outcome in the social

102 perspective [30]. Moreover, tool development has remained to be a challenge despite numerous

103 theoretical underpinnings that tackle this concept in various scales. Only few procedures within

104 the existing literature (e.g., Cutter et. al. [31]; Peacock et. al [32]; Sherrieb et al. [33]), however,

105 suggested how the concept could be quantified and be used to categorize or to compare

106 communities.

107

108

109

\subsection{Disaster-resilient components based on Analytic Hierarchy Process}

This study proposed a novel approach to developing a tool for quantifying disaster

110 resilience in the Philippines by synthesizing national-level disaster resilience components using 111 the Analytic Hierarchy Process (AHP). The AHP is a methodological approach to decision 112 making that can be applied to resolve highly complex problems involving multiple scenarios, 113 criteria, and actors [34]. This approach has been used in various studies that aimed to enhance 
114 development in different sectors such as tourism [35,36], environmental and natural resources 115 [37], forestry [38], coastal management [39], and disaster and risk management [40,41]. As a decision system, the AHP is valuable for using human cognition in determining the 117 relative importance among a collection of alternatives using paired comparisons [42]. Corollary, 118 the important alternatives can be used to develop an evaluation tool for assessing performance of 119 business firms [43] or to select the best design concept in product development [44]. On the 120 other hand, it is found effective when assigning weights for indicators of disaster risks and 121 vulnerability indices [45] or when ranking risk factors in a flood risk assessment model [46]. 122 With the AHP, important household attributes can also be selected to serve as indicators that 123 measure and categorize household vulnerability to climatic risk [47].

124 In this study, the AHP was used to determine the criteria and elements that best described 125 a disaster-resilient coastal community at the local level by subjecting the components of a risk 126 management and vulnerability reduction system in the Philippines [16,20] in a process of 127 prioritization. An outcome framework for disaster-resilient coastal communities was designed 128 based on priority components and were used to determine the outcome indicators of a composite 129 index for a disaster resilient coastal community. The development of an index, with participation 130 of selected members from a low vulnerability coastal community, was primary in the country. 131 This tool can then be used to evaluate the resilience of local coastal communities from disasters.

\subsection{Development of the AHP Model}


The components that best described a disaster-resilient coastal community were presented

on a three-tier hierarchy representing relevant aspects of community resilience in an AHP model

(Figure 1), wherein the top tier represented a goal related to the problem. The second tier consisted of seven criteria determined based on resilience components in Twigg [16]. These included Environmental and Natural Resource Management (ENRM), Human Health and Well Being (HWB), Sustainable Livelihoods (SL), Social Protection (SP), Financial Instruments (FI), Physical Protection and Structural and Technical Measures (PPST), and Planning Regimes (PR).

Finally, attribute elements for each criterion characterizing disaster-resilient communities represented by $C$ and risk-reduction-enabling environments represented by $E$ formed the bottom tier. For example, the elements that characterized disaster-resilient communities for the criterion ENRM were ENRMC1, ENRMC2..., and ENRMC5, while the elements that characterized riskreduction-enabling environment were ENRME1, ENRME2..., and ENRME5, wherein the numbers $1,2, \ldots n$ correspond to a specific attribute element (Table 1 ).

In each tier, the number of criteria and their elements compared were maintained within the suggested limits in a comparison scheme where seven is the maximum [42]. With this consideration, decision makers reduced attribute elements of the PPST and SL criteria to seven components based on their relevance and applicability in the local context.

\subsection{Local decision makers}

The process of prioritization for components of a disaster-resilient coastal community was conducted in March 2012 in the municipality of Baler, province of Aurora, the Philippines (Figure 2). In this municipality, Zabali was considered the least vulnerable coastal community in an assessment that measured their susceptibility to various hazards [48]. The familiarity and 
160 experience of communities in Zabali in mitigating the sources of vulnerability were the major

161 reasons for considering them as local experts. These community members, along with service

162 providers on coastal management and disaster planning from academia and local governments,

163 were considered decision makers during the prioritization. They were all selected based on their

164 experience, skills, knowledge and practices related to different aspects of addressing vulnerable 165 communities.

166

\section{2.3. Weights of alternatives in a consistent matrix}

168

169

170

171

172

173

174

175

176

177

178

179

180

181

With reference to the AHP model, important alternative criteria and elements associated with achieving a disaster-resilient coastal community were identified using paired comparisons and ratio-scale measurement. This is described by the formula:

$$
n \cdot(n-1) / 2 \text {, }
$$

where $n$ is the number of alternative criteria or elements $\left(a_{1}, a_{2}, \ldots, a_{n}\right)$ in a judgment of prioritization $[42,49]$. In this case, there were 21 comparisons involved in a matrix for seven alternative criteria, while comparisons of attribute elements for each criterion varied from three to 21 and were composed of three to seven alternatives.

Each product of a paired comparison was considered an expression of the decision maker's relative preferences for one alternative over another based on a set of fundamental scales (Table 2) composed of values ranging from 1 to 9 [34,49]. Coyle [50] explained that when a decision maker decided that alternative $i$ was equally important to another alternative $j$, a comparison represented by $a_{i j}=a_{j i}=1$ was expected. Nonetheless, when alternative $i$ was considered extremely important compared with alternative $j$, the calculation matrix score was 
182 based on $a_{i j}=9$ and $a_{j i}=1 / 9$. The distribution of these scores in a square matrix resulted in a 183 reciprocal matrix [51], represented as:

$$
A=\left[a_{i j}\right]=\left\{\begin{array}{cccc}
1 & a_{i j} & \ldots & a_{1 n} \\
1 / a_{i j} & 1 & \ldots & a_{2 n} \\
\vdots & \vdots & & \vdots \\
1 / a_{1 n} & 1 / a_{2 n} & \ldots & 1
\end{array}\right\},
$$

185 186 187 188 189 achieved. $\lambda_{\max }[52]$.

where $A=\left[a_{i j}\right]$ is a representation of the intensity of the decision maker's preference for one over another compared alternative $a_{i j}$ and for all comparisons $i, j=1,2, \ldots n$. Decision makers facilitated the comparisons of alternative criteria or elements in two rounds until the scores were considered stable. Stability was reached when a certain consensus on a sum of scores was

Multiplying together the comparison scores of alternative criteria or elements in each row of the reciprocal matrix and then taking the $\mathrm{n}^{\text {th }}$ root of that product generated a good approximation of the element weights for each alternative [50], as follows:

$$
\text { Element weight }=\sqrt[n]{a_{i j} \cdot a_{n j} \cdot \cdots \cdot a_{n n}} .
$$

The weights in a column were summed, and that sum was used to obtain the normalized eigenvector $w_{i j}$ for that alternative, as shown by the formula:

$$
w_{i j}=\frac{\text { Element weight }}{\text { EElement weights in column }} \text {. }
$$

When matrix $A$ was multiplied by the vector $w_{i j}$, the operation resulted in a new priority vector $n w_{i j}$. A similar $n w_{i j}$ value was obtained when $w_{i j}$ was multiplied by the maximum eigen value

The importance of criteria and elements in achieving a disaster-resilient coastal community was determined by a high $n w_{i j}$ value for each criterion or element. This vector is the sum of products of elements in each row and the normalized $w_{i j}$ in each column [50], as follows: 
204 In a consistent matrix, $n w_{i j}$ values for each criterion or element became weights, from which the 205 rank of each of the other alternatives in the respective set of components was determined.

\subsection{Consensus building}

A consensus on the final scores of every paired comparison of criteria or elements was reached in a process involving the Delphi technique [53.54]. The final scores were computed based on a geometric mean of all scores given by decision makers for each paired comparison [55]. Once a consensus was reached, a summary of final scores for each paired comparison was entered into a matrix or decision table.

The scores, as well as their $n w_{i j}$ values, were accepted when they reached a certain level

214 of consistency, as determined by a consistency index $C I$ computed by Eq. 6:

$$
C I=\left(\lambda_{\max }-n\right) /(n-1),
$$

216 where $\lambda_{\max }$ is the maximum eigen value computed by averaging all individual eigen values $\lambda$, 217 and $n$ is the number of elements (or criteria) subjected to a priority judgment. Each individual $218 \lambda$ was computed by dividing the $n w_{i j}$ by their normalized values $w_{i j}$

$$
\lambda=\frac{\text { nwij }_{\text {ij }}}{\text { Normalized } w_{i j}} .
$$

The computed $C I$ was then compared with a random consistency index $R I$ of the 221 generated paired comparison matrix to determine the consistency ratio $C R$ (Table 3). The $C R$ 222 established whether the decision maker's judgment scores or weights were accepted, where $C R$ $223 \leq 0.10$ was deemed acceptable [49,52], based on Eq. 8:

$$
C R=\frac{C I}{R I} \text {. }
$$


A top-down process was applied to select and evaluate the criteria and elements. In this 226 process, all criteria were first evaluated, and once a criterion was found desirable for achieving a 227 disaster-resilient coastal community, its attribute elements were selected and subjected to 228 comparisons. New priority vector $n w_{i j}$ values of the criteria and elements that fell within the 229 acceptability range of $C R \leq 0.10$ were adopted as their respective weights, and were used as basis 230 to determine their rank within their respective group.

In each tier of the hierarchy, an exploratory approach to adopt $\geq 70 \%$ representation of the 232 criteria and elements that had been subjected to paired comparisons was considered. This means 233 that the sum of the ratio of weights of the top criteria or elements to their respective overall 234 weight was $\geq 70 \%$, as shown in Eq. 9 .

$$
\sum \frac{\text { Individual nwij }}{\text { Overall }_{\text {if }}} \geq 70 \%
$$

236 This percentage was thought to provide an optimal number of criteria and elements to represent 237 each level. Hence, other criteria or elements were disregarded as being of low importance and 238 having relatively small impact on the overall objective.

\section{RESULTS}

\subsection{Selected criteria and elements}

The comparison matrix at the criterion level was consistent with a value of 0.09 (Table 4).

245 Based on the weights of alternatives at this level, Environment and Natural Resources 246 Management (ENRM) and Physical Protection and Structural Technical Measures (PPST) were 247 ranked as the highest and lowest criteria, respectively. The highest ranked criteria, i.e., 
248 Environment and Natural Resources Management (ENRM), Sustainable Livelihood (SL), Social

249 Protection (SP), and Planning Regime (PR), were selected by the sum of their weights and

250 accounted for $72 \%$ of the overall weights of the criteria being compared. Their attribute elements

251 were then subjected to further comparison, and high-ranking elements were subsequently

252 selected.

253 For Environment and Natural Resources Management (ENRM), the elements that 254 characterized disaster-resilient communities were ENRMC1, ENRMC2, and ENRMC4, which 255 accounted for $74 \%$ of the overall alternatives (Table 5), whereas the combination of ENRMC1, 256 ENRMC2, and ENRMC3 accounted for $71 \%$ of the most important attributes that describe risk257 reduction-enabling environment. The matrices of comparisons for these attribute elements fell 258 within a $C R$ value of 0.10 and 0.09 , respectively.

259 Subsequent procedures for selecting and evaluating attribute elements were conducted for 260 Sustainable Livelihood (SL), Social Protection (SP), and Planning Regime (PR). For Sustainable 261 Livelihood (SL), the elements SLC1, SLC3, SLC4, SLC5, and SLC7 were selected as elements 262 that describe disaster-resilient communities, whereas SLE1, SLE2, SLE3, and SLE7 were 263 selected as elements that describe risk-reduction-enabling environment (Table 5). These 264 elements accounted for $78 \%$ and $75 \%$, respectively, of each attribute group.

265 For Social Protection (SP), the elements SPC1, SPC2, and SPC3 (77\%) and SPE1 and 266 SPE3 (80\%) were selected to represent elements that described disaster-resilient communities 267 and that described risk-reduction-enabling environment, respectively. Finally, the elements 268 PRC1 and PRC3 (80\%) that described disaster-resilient communities, as well as PRE1, PRE2, 269 and PRE4 (82\%) that described risk-reduction-enabling environment were considered the most 270 important elements for criterion Planning Regime (PR). 


\section{DISCUSSION}

\subsection{Priority criteria and elements}

Environmental and Natural Resources Management (ENRM) was the most important

277 criterion for describing disaster-resilient communities because ecosystem benefits are crucial to 278 communities. Orencio and Fujii [48] referred to coastal resources in Baler as an important 279 resource, as most individuals depend on such resources for food and livelihood. This recognition 280 of ENRM as an important criterion for resilience can be attributed to the decision maker's idea of 281 sustainable ecosystem services that can be derived from a healthy resource [56].

282 Sustainable Livelihoods (SL) and Social Protection (SP) represented the desires of 283 communities to achieve systems that ensure livelihood and security, respectively, based on the 284 recognition of environmental and social hazards that affect their lives. Communities understood 285 that their level of susceptibility to hazards was caused by their fragile livelihood systems. For 286 instance, most people in coastal villagers tended to seek employment in fishing industries, 287 whereas upland people focused on farming and raising livestock [57]. Others became self288 employed and ventured into small-scale businesses.

289 Typically, the open-access system and minimal capitalization of fisheries allows this to 290 be a common safety net for individuals who cannot find permanent employment. Because of the 291 very limited resources and lack of security and income stability, however, communities found it 292 difficult to cope when struck by recurring hazards. Thus, communities believed that their ability 
293 to adapt and recover was related to sustainable livelihood, and this could be enhanced by the 294 support of an institution that promotes equitable distribution of resources.

The Planning Regimes criterion (PR) describes community aspirations to achieve a

296 process that facilitates implementation mechanisms based on participation by communities as a

297 vital element of success. Most communities regard implementation as an offshoot of careful 298 planning. Therefore, they recognized that many institutions lacked proper policy and

299

\subsection{Delphi and AHP}

To obtain a consensus on the scores in a paired comparison of alternatives in the AHP model, the Delphi technique was found to be effective in a multi-stakeholder decision-making process. However, the process required a strong facilitator who could harmonize the different perspectives of decision makers into a single objective. Despite similar experiences and exposures to risk and disasters, the social status (e.g., education) and level of engagement in disaster management systems varied among decision makers, resulting in a variety of opinions about each alternative.

The Delphi was particularly important during the comparison of the alternatives at the level of attribute elements. Decision makers tended to regard alternatives as having similar objectives, which made comparison difficult. The role of the facilitator was to expound on the differences among alternatives and to organize the opinions of stakeholders. In this case, the group was able to establish a common view on each alternative prior to the paired comparison. 

decision makers because some had not used a quantitative measure to assess importance and to compare two alternatives. Comparisons were far more difficult and time consuming when there were seven alternatives because this could require 21 comparisons. Decision makers resolved a matrix that involved only three alternatives, as shown by their high consistency rates (Table 5). Less consistent rates were obtained in two rounds when there were more than three alternatives.

323 from each other in the matrix (Eq. 2) were scored following a rule of thumb. In this rule, when a 324 judgment favored the alternative on the left-hand side of the matrix, an actual judgment value 325 (e.g., 1, 2,..9) was used for scoring, and the reciprocal value (e.g., $\frac{1}{2}, \frac{1}{3}, \ldots, \frac{1}{9}$ ) was used when the 326 judgment favored the alternatives placed on the right-hand side of the matrix [58].

\subsection{Framework index and metrics to evaluate disaster-resilient communities}

With reference to important criteria and attribute elements selected using the hierarchical structure in the AHP model, the top four criteria were considered when designing the disasterresilience outcome framework (Figure 3). This framework was used as a basis for developing the outcome indicators for the composite index, which will serve as a tool to evaluate a disaster333 resilient coastal community at the local level.

To view disaster resilience only with its outcome, however, creates a limitation in placing 335 emphasis on the human role in disaster-risk management [29]. While, outcome components are important for the real achievements in terms of community empowerment and capacity building,

337 process components should also be considered to provide for an understanding of a community 338 and for the sustainability of a disaster-resilience program [59]. Hence, the measure of coastal 
community disaster-resilience was developed with consideration on both outcome and process components that the community had achieved and implemented.

Meanwhile, since only criteria and elements as outcome components were provided by the AHP (Figure 4), process components were developed with respect to the Integrated Community-based Risk Reduction (ICBRR) model of the Canadian Red Cross (CRC) and the Indonesian Red Cross Society (PMI) (Figure 5). This framework has 10 specific activities for establishing disaster-resilient communities, which include implementation of risk-reduction measures [59]. As a result, a composite index for a disaster-resilient coastal community (Figure 6) was developed based on a aggregate measure of an overall outcome indicator computed based on four important AHP criteria and their elements, and an overall process indicator that was quantified from 10 specific activities of the ICBRR.

The fundamental metrics for the index followed a weighted linear combination (WLC) of indicators for outcome and process components. For the WLC, outcome indicators were assigned weights based on a weighting system to provide a basis for intensifying the indicator scores. These were taken from the $n w_{i j}$ values that determined the ranks in the AHP model and were computed with the minimum-maximum method following Eq. 10:

$$
W_{n}=\left(W_{\text {act }}-W_{\min }\right) /\left(W_{\max }-W_{\min }\right),
$$

where $W_{n}$ is the normalized weight of a criterion or element, and $W_{\text {act }}$ is the actual weighted values of a criterion or element within the compared set of alternatives, whereas $W_{\max }$ and $W_{\min }$ are the maximum and minimum weights, respectively, of criteria or elements within that set. The normalized weights of the selected criteria and elements were shown in Table 6.

During the design of the metric computations for the attribute elements for ENRM, SL, SP, and PR, only two elements characterizing disaster-resilient communities for the criterion PR 
362 and the external enabling environment for the criterion SP were selected. These criteria only had

363 three elements that are used for comparison, and inclusion of the lowest ranking alternative 364 resulted in a normalized weight of zero. Because weights were used to intensify the scores in the 365 proposed assessment, those elements with weights of zero were excluded from the selection. Initially, to compute for the outcome indicator, each criterion was measured based on

367 attribute element scores $E S$. The $E S$ were based on a level of attainment or success in designating 368 a distinct step in disaster risk reduction (DRR) [16]. Using this scale, Level 5 was considered the 369 highest, and Level 1 was the lowest in terms of degrees of implementation. However, we 370 proposed the addition of another level to modify this to a six-point scale, where 0 was the lowest 371 and referred to situation where DRR activities were non-existent and were not implemented 372 (Table 7).

All ES corresponding to the criterion were summed to obtain the criteria scores using Eq.

374 11:

375

$$
C S=\sum_{j=0}^{j=5} C\left(W_{i} E S_{j}\right)+\sum_{j=0}^{j=5} E\left(W_{i} E S_{j}\right),
$$

376 where $C S$ represents the overall criterion score, $C$ represents the attribute elements for disaster377 resilient communities, $E$ represents the attribute elements for risk-reduction-enabling 378 environment, $W_{i}$ represents the weights of all attribute elements $i$, and $R_{j}$ represents the rank or 379 values of attribute elements $j$. All $C S$ values were combined to determine the overall outcome380 indicator score, as shown in Eq. 12:

$$
O S=\sum_{j=0}^{j=5} C\left(W_{i} C S_{j}\right)
$$

382 where $O S$ is the overall outcome-indicator score, $C$ represents the criteria, $W_{i}$ represents the 383 weights of criteria $i$, and $C S_{j}$ represents the scores for each criterion $j$. 
386 where $P S$ represents the overall process-indicator score, $P$ represents process indicators based on 387 the 10 activities of the ICBRR model, $W_{i}$ represents the weights of indicators $i$ with equal values 388 that sum to 1 , and $R_{j}$ represents the ranks or values of process indicator $j$. Similarly, the ranking or scoring of indicator values followed the modified six-level scale (Table 7), with 5 representing completely attained. It should be noted that because indicators have $W_{i}$, the sum of which equals $1, W_{i}$ for each corresponding process indicator was 0.10 .

Finally, the overall index score was determined by combining the process- and outcomeindicator scores, as shown in Eq. 14:

$$
I S=P S W_{i}+O S W_{i}
$$

where $I S$ represents the overall index score, $P S$ represents the overall process-indicator score, $O S$ represents the overall outcome-indicator score, and $W_{i}$ represents the weights of the process and outcome indicators $i$. Because the process and outcome indicators have equal $W_{i}$, the sum of 398 which equals $1, W_{i}$ for each indicator was 0.50 .

\subsection{Limitations of the proposed index}

In this study, we developed an index for a disaster-resilient coastal community with the

402 ability to objectively assess the degree of attainment of each critical indicator for both process 403 and outcome components. The outcome indicators were developed from the synthesis of disaster 404 resilience components using the AHP. However, the process indicators developed based on the 405 Integrated Community-based Risk Reduction (ICBRR) model to assess disaster-resilience of a 406 coastal community still depend on some assumptions, as risk-reduction programs implemented at

407 the community level in the Philippines followed the Citizen-Based and Development-Oriented 
408 Disaster Response (CBDODR) and the Community-Based Disaster Risk Management 409 (CBDRM) approaches. Concepts may vary among approaches, but most activities were similar. 410 Hence, the proposed process indicators could be assessed at the activity level to limit bias 411 resilience measurements.

412 The proposed WLC measurement for the disaster-resilience index relied on the weights 413 and scores assigned to each indicator. The weights for the outcome indicators varied since they 414 were based on values derived from the AHP, but equal weights were assigned to process 415 indicators. Since weights were used to intensify the scores in the assessment, this may pose some 416 limitations in providing a quality measure for process indicators. This limitation can be resolved 417 by undertaking a further AHP for the process indicators. Nevertheless, a score range of 0 to 5 to 418 rank both process and outcome indicators could be used for more objective evaluation.

419 Further agreements on the use of the ICBRR approach to model disaster-resilient 420 communities could be considered, as this may also serve as a framework to evaluate local DRR 421 activities. Reports regarding the International Federation of the Red Cross' intentions to 422 implement this approach in Southeast Asia and to develop communities into disaster response 423 teams could provide a good opportunity to enhance the Philippines' local disaster-management 424 and risk-reduction system.

425

426 4.5. Pilot assessment

427 The next important step in the process is a pilot assessment in a coastal community using 428 the composite index. The community-based assessment will involve individuals in scoring and 429 ranking both process and outcome indicators based on a fundamental rating scale that was 430 developed to categorize the quality of community interventions in undertaking DRR. A 
431 sensitivity analysis will be applied to identify important flaws and subsequent development

432 needs. This analysis will further refine the exploratory approach for criterion and element

433 selection, such as the arbitrary decision to select overall criterion and element scores that

434 summed to $\geq 70 \%$. In this way, the relationship that existed between selected criteria and

435 elements could be properly defined, and the underlying structure would likely provide a quality

436 benchmark measure of disaster- resilient coastal communities.

437

438

439

\section{CONCLUSIONS}

At the national scale, a number of disaster- and risk-management-related systems have

441 been developed, but there have been limited attempts to synthesize their components and select

442 the most important ones to be used in undertaking local assessments. The Analytic Hierarchy

443 Process (AHP), which involves paired comparisons of various alternatives, provided a potential

444 method for this purpose. AHP was found effective in selecting the criteria and elements that best

445 described a disaster-resilient coastal community with the participation of local decision makers.

446 The consensus-building process by which criteria and elements were to be selected and

447 evaluated was simplified by a top-down approach. A Delphi technique, as facilitated by a strong

448 facilitator however, was noteworthy to achieve the objective preferences of decision makers.

449 Based on the results, four criteria, i.e., Environmental and Natural Resource Management

450 (ENRM), Sustainable Livelihoods (SL), Social Protection (SP), and Planning Regime (PR), were

451 considered the most important criteria to describe outcomes for a disaster-resilient coastal

452 community. 
With reference to a weighted-linear combination of the process and outcome components,

454 a composite index for disaster resilient coastal community was designed. The important criteria 455 and their representative attribute elements from the AHP served as outcome indicators, whereas 456 process indicators were developed in consideration of the Integrated Community-Based Risk 457 Reduction (ICBRR) model of Canadian Red Cross and the Indonesian Red Cross Societies. This 458 tool is expected to contribute to a quantified measurement of disaster-resilience, to minimize a 459 bias local assessment and to enhance a localized disaster-risk reduction approach.

\section{ACKNOWLEDGEMENTS}

This research was supported by a Japanese Government (Monbukagakusho) Scholarship.

464 The authors would like to acknowledge the Hokkaido University Sustainable Low-carbon 465 Society Project, Aurora State College of Technology, and Aurora Marine Research Development 466 Institute for providing logistics and manpower support.

467 468

\section{REFERENCES}

470 [1] Goklany, I. Death and Death Rates Due to Extreme Weather Events, International Policy 471 Network, Third Floor, Bedford Chambers, The Piazza, London, WC2E 8HA UK, 2007. 472 Accessed on November 22, 2012 from http://www.csccc.info/reports/report_23.pdf.

473 [2] Stolton S., N. Dudley, and J. Randall, Arguments for Protection- Natural Security Protected 474 Areas and Hazard Mitigation, World Wide Fund for Nature, 2008. ISBN: 978-2-88085-280-1. 
475 [3] Bhavnani, R., M. Owor, S. Vordzorgbe and F. Busquet, Report on the Status of Disaster Risk 476 Reduction in Sub-Saharan African Region, Commission of the African Union, UNISDR, and 477 World Bank, 2008. Accessed on November 22, 2012 from http://ipcc478 wg2.gov/SREX/report/njlite?chapter=\&page=4.

479 [4] UN International Strategy for Disaster Reduction (UNISDR), Living with Risk: A Global 480 Review of Disaster Reduction Activities, 2004. 429 p. ISBN/ISSN: 9211010640.

481 [5] Stockholm International Water Institute (SIWI), Making Water a Part of Economic 482 Development, The Economic Benefits of Improved Water Management and Services, 483 Governments of Norway and Sweden, 2005. Accessed on November 22, 2012 from 484 http://www.who.int/water_sanitation_health/watandmacrtoc.pdf.

485 [6] Creel, L., Ripple Effects: Population and Coastal Regions, Making the Link. Population 486 Reference Bureau, Washington DC 20009 USA, 2003. Accessed on November 22, 2012 from 487 http://www.prb.org/Publications/PolicyBriefs/RippleEffectsPopulationandCoastalRegions.aspx.

488 [7] Boesch, D.F., J.C. Field, and D. Scavia., The Potential Consequences of Climate Variability 489 and Change on Coastal Areas and Marine Resources: Report of the Coastal Areas and Marine 490 Resources Sector Team, U.S. National Assessment of the Potential Consequences of Climate 491 Variability and Change, U.S. Global Change Research Program, NOAA Coastal Ocean Program, 492 Silver Spring, MD, 2000. 163 p. Accessed on November 22, 2012 from 493 http://www.cop.noaa.gov/pubs/das/das21.pdf

494 [8] IPCC, Climate change 2007: Impacts, Adaptation, and Vulnerability. Contribution of 495 Working Group II to the Fourth Assessment Report of the Intergovernmental Panel on Climate 496 Change. M.L. Parry, O.F. Canziani, J.P. Palutikof, P.J. van der Linden and C.E. Hanson, Eds, 
497 Cambridge University Press, Cambridge, UK, 2007. 976 p. Accessed on November 22, 2012

498 from http://www.ipcc.ch/pdf/assessment-report/ar4/wg2/ar4_wg2_full_report.pdf.

499 [9] U.S. Indian Ocean Tsunami Warning System Program (USIOTWSP), How Resilient is Your

500 Coastal Community? A Guide for Evaluating Coastal Community Resilience to Tsunamis and

501 Other Coastal Hazards, United States Agency for International Development and Partners,

502 Bangkok, Thailand, 2007. 144 p.

503 [10] Blaikie, P., T. Cannon, I. Davis, and B. Wisner, At Risk: Natural Hazards, People's

504 Vulnerability, and Disasters. (1 ${ }^{\text {st }}$ Edition) London, Routledge, New York, 1994.

505 [11] Cannon, T., Vulnerability analysis and the explanation of "natural" disasters, in: A. Varley

506 (ed.) Disasters, development and the environment, Chichester: John Wiley 1994, pp. 13-30.

507 [12] Adger, W. N., T. Hughes, C. Folke, S. R. Carpenter, and J. Rockström, Social-ecological

508 Resilience to Coastal Disasters, Science. 309 (2005): 1036-1039.

509 [13] Cutter, S.L., C.G. Burton, and C.T. Emrich, Disaster resilience indicators for benchmarking 510 baseline conditions. Journal of Homeland Security and Emergency Management. Volume 7: 1

511 (2010) 1-22.

512 [14] McEntire D.A., Sustainability or Invulnerable Development? Proposals for the Current Shift 513 in Paradigms. Australian Journal of Emergency Management, 15:1 (2001) 58-61.

514 [15] Buckle, P., G. Marsh, and S. Smale, Assessing Resilience and Vulnerability: Principles, 515 Strategies and Actions, Emergency Management, Australia, Project 15/2000, 2001. Accessed on 516 November 22, 2012 from http://www.eird.org/cd/on-better-terms/docs/Buckle-Marsh-Smale-

517 Assessing-Resilience-Vulnerability-Principles-Strategies-Actions.pdf.

518 [16] Twigg, J., Characteristics of a Disaster-resilient Community: A Guidance Note, Version 1.

519 UK Department for International Development's Disaster Risk Reduction Interagency 
520 Coordination Group, London, 2007. Accessed on November 22, 2012 from

521 https://practicalaction.org/docs/ia1/community-characteristics-en-lowres.pdf.

522 [17] Vos, F., J. Rodriguez, R. Below, D. Guha-Sapir. Annual Disaster Statistical Review 2009:

523 The Numbers and Trends. Brussels: Center for Research on the Epidemiology of Disasters, 2010.

524 Accessed on November 22, 2012 from http://cred.be/sites/default/files/ADSR_2009.pdfa.

525 [18] Citizen's Disaster Research Center (CDRC), Philippine Disaster Report. Disaster Statistics

526 2009. Philippines, 2009. Accessed on November 22, 2012 from http://www.cdrc-phil.com/wp-

527 content/uploads/2009/08/2009-Philippine-Disaster-Report.pdf.

528 [19] Asian Disaster Preparedness Center (ADPC), Monitoring and Progress on Community529 based Disaster Risk Reduction in the Philippines, European Commission, United Nations 530 Economic and Social Commission for Asia and the Pacific, Partnerships for Disaster Risk 531 Reduction in Southeast Asia, Phase 4 Project, 2008. Accessed on November 22, 2012 from 532 http://www.adpc.net/v2007/programs/CBDRM/Publications/Downloads/Publications/Philipines 533 Update.pdf.

534 [20] National Economic and Development Authority (NEDA), UNDP and ECHO, 535 Mainstreaming Disaster Risk Reduction in Sub-national Development and Land Use/ Physical 536 Planning in the Philippines, 2008. ISBN 978-971-8535-23-3.

537 [21] World Bank (WB), Philippine Environment Monitor 2005, Coastal and Marine Resources 538 Management, Metro Manila, Philippines, 2005. Accessed on November 22, 2012 from 539 http://siteresources.worldbank.org/INTPHILIPPINES/Resources/PEM05-complete.pdf .

540 [22] Israel, D., E. Adan, N. Lopez, and J. de Castro, Household Perceptions on the Long-Term 541 Impact of Coastal Resources Management in Panguil Bay, Philippine Journal of Development, $542 \quad 31: 1(2004) 107-134$. 
543 [23] Heijmans, A. and L. Victoria, Citizenry-Based and Development Oriented Response:

544 Experiences and Practices in Disaster Management of the Citizen's Disaster Response Network 545 in the Philippines, Center for Disaster Preparedness, Quezon City, 2001. 118 p.

546 [24] Luna, E. M., Endogenous System of Response to River Flooding: The Case of Bula 547 Camarines Sur: Towards an Appropriate and Integrated Development and Disaster Management 548 Planning, Doctorate Dissertation, School of Urban and Regional Planning, University of the 549 Philippines, Unpublished results.

550 [25] UN International Strategy for Disaster Reduction (UNISDR), Building Disaster Resilient 551 Communities Good Practices and Lessons Learned, A Publication of the "Global Network of 552 NGOs” for Disaster Risk Reduction Geneva, 2007. 67 p. Accessed on November 22, 2012 from 553 http://www.unisdr.org/we/inform/publications/596.

554 [26] Olwig, M., Multi-sited resilience: The mutual construction of "local" and "global" 555 understandings and practices of adaptation and innovation, Applied Geography, 33 (2012) 112556 118. doi.org/10.1016/j.bbr.2011.03.031.

557 [27] Holling, C.S., Resilience and stability of ecological systems, Annual Review of Ecology and 558 Systematics, 4 (1973) 1-23.

559 [28] Walker, B.H, L.H. Gunderson, A.P. Kinzing, C. Folke, S.R. Carpenter and L. Schultz, A 560 Handful of Heuristics and Some Propositions for Understanding Resilience in Social-Ecological 561 Systems, Ecology and Society, 11 (2006) 1:13.

562 [29] Manyena, S.B., The concept of resilience revisited, Disasters, 30:4 (2006) 433-450.

563 [30] Adger, N.W., Social and ecological resilience: Are they related? Progress in Human 564 Geography, 24 (2000) 347-363. 
565 [31] Cutter, S.L., L. Barnes, M. Berry, C.G. Burton, E. Evans, E.C. Tate and J. Webb, A place566 based model for understanding community resilience to natural disasters, Global Environmental 567 Change, 18 (2008) 598-606.

568 [32] Peacock, W.G., S.D. Brody, W.A. Seitz, A.V. Merrell, S. Zahran, R.C. Harriss and R.R. 569 Stickney, Advancing the resilience of coastal localities: Implementing and sustaining the use of 570 resilience indicators, Final report prepared for the CSC and NOAA, College Station, TX: Hazard 571 Reduction and Recovery Center, 2010. Accessed on November 22, 2012 from 572 http://hrrc.arch.tamu.edu/media/cms_page_media/558/10-02R.pdf.

573 [33] Sherrieb, K., F.H. Norris and S. Galea, Measuring capacities for community resilience, 574 Social Indicators Research, 99:2 (2010) 227-247.

575 [34] Satty, T.L., The Analytic Hierarchy Process. McGraw-Hill, New York, 1980. 257 p.

576 [35] Filipovic, M., The Analytic Hierarchy Process as a Support for Decision Making, 2007. 577 UDC 519.816:004.42]:338.48. Accessed on November 22, 2012 from 578 http://www.doiserbia.nb.rs/img/doi/1450-569X/2007/1450-569X0716044F.pdf.

579 [36] Ok, K., T. Okan, and E. Yimaz, A comparative study on activity selection with multi580 criteria decision-making techniques in ecotourism planning, Scientific Research and Essays, 6 :6 581 (2011) 1417-1427.

582 [37] Schmoldt, D.L., J. Kangas and G.A. Mendoza, Basic principles of decision making in 583 natural resources and the environment, in: Schmoldt, D.L., J. Kangas, G.A. Mendoza and M. 584 Pesonen (Eds.), The Analytic Hierarchy Process in Natural Resource and Environmental 585 Decision Making, Managing Forest Ecosystems Series, vol. 3. Kluwer Academic Publishers, 586 Dordrecht, 2001. pp. 1-15. 
587 [38] Samari, D., H. Azadi, K. Zarafshani, G. Hosseininia, and F. Witlox, Determining 588 appropriate forestry extension model: Application of AHP in the Zagros area, Iran, Forest Policy 589 and Economics, Vol. 15. (2012) 91-97.

590 [39] Ryu, J., T. Leschine, J. Nam, W.K. Chang and K. Dyson, A resilience-based approach for 591 comparing expert preferences across two large-scale coastal management programs, Journal of 592 Environmental Management, Volume 92:1 (2011) 92-101.

593 [40] Carreno, M.L., O.D. Cardona, and A.H. Barbat, A disaster risk management performance 594 index, Natural Hazards, Vol. 41:1 (2007) 1-20.

595 [41] Chen, G., L. Tao, and H. Zhang, Study on the methodology for evaluating urban and 596 regional disasters carrying capacity and its application, Safety Science, Vol. 47:1 (2009) 50-58.

597 [42] Satty, T.L., Fundamentals of Decision Making and Priority Theory with Analytic Hierarchy 598 Process (Analytic Hierarchy Process Series, Vol. 6), RWS Publications: Pittsburgh, 2001. 477 p. 599 [43] Yang, J. and P. Shi, Applying Analytic Hierarchy Process in Firm's Overall Performance 600 Evaluation: A Case Study in China, International Journal of Business. 7:1 (2002).

601 [44] Ariff, H., M.S. Salit, N. Ismail and Y. Nukman, Use of Analytical Hierarchy Process for 602 Selecting the Best Design Concept, Jurnal Teknologi, 49 (A) 2008: 1-18.

603 [45] Cardona, O.D. and M.L. Carreno, Updating the Indicators of Disaster Risk and Risk 604 Management for the Americas, Journal for Integrated Disaster Risk Management 1:1 (2011). 605 ISSN: 2185-8322. DOI 10.5595/idrim.2011.0014.

606 [46] Yang, X., J. Zhou, J. Ding, Q. Zou and Y. Zhang, A Fuzzy AHP-TFN Based Evaluation 607 Model of Flood Risk Analysis, Journal of Computational Information Systems. 8:22 (2012) $608 \quad 9281-9289$. 
609 [47] Eakin, H. and L.A. Bojórquez- Tapia, Insights into the Composition of Household 610 Vulnerability from Multi-criteria Decision Analysis, Global Environmental Change. 18:1 (2008) $611 \quad 112-127$.

612 [48] Orencio, P.M. and M. Fujii, An Index to Determine Vulnerability of Communities in a 613 Coastal Zone: A Case Study of Baler, Aurora, Philippines, AMBIO: A Journal of the Human 614 Environment, 2012. DOI: 10.1007/s13280-012-0331-0.

615 [49] Satty, T.L., and L.G. Vargas, Prediction, Projection and Forecasting. Kluwer Academic 616 Publishers, Boston, Massachusetts. 1991. 251 p.

617 [50] Coyle, G., Practical Strategy, Open Access Materials, Analytic Hierarchy Process, Pearson 618 Education Limited. 2004. Accessed on November 22, 2012 from 619 http://www.booksites.net/download/coyle/student_files/AHP_Technique.pdf.

620 [51] Alonso, J. and T. Lamata, Consistency in the Analytic Hierarchy Process: a New Approach, 621 International Journal of Uncertainty, Fuzziness and Knowledge-Based Systems, 14:4 (2006) 445622459.

623 [52] Satty, T.L., Multi-criteria Decision Making: The Analytic Hierarchy Process, Planning, 624 Priority Setting, Resource Allocation, RWS Publications, Pittsburgh, Pennsylvania. 1990. 287 p. 625 [53] Kaynak, E. and J.A. Macaulay, The Delphi Technique in the Measurement of Tourism 626 Market Potential: The Case of Nova Scotia, Tourism Management, 5:2 (1984) 87-101.

627 [54] Richey, J.S., B.W. Mar, and R.R. Horner, The Delphi Technique in Environmental 628 Assessment I: Implementation and Effectiveness, Journal of Environmental Management, 21:1 629 (1985) 135-146.

630 [55] Aczel, J., and T.L. Satty, Procedures for Synthesizing Ratio Judgments. Journal of 631 Mathematical Psychology, 27 (1983) 93-102. 
632 [56] Grant, F., J. Young, P. Harrison, M. Sykes, M. Skourtos, M. Rounsevell, T. Kluvánková633 Oravská, J. Settele, M. Musche, C. Anton, and A. Watt, Ecosystem Services and Drivers of 634 Biodiversity Change, Report of the RUBICODE E-Conference, 2008. Accessed on November 22, 6352012 from http://www.rubicode.net/rubicode/RUBICODE_e-conference_report.pdf.

636 [57] Mohanty, S., Multi-sector Contributions in Reducing Vulnerability to Natural Disaster: A 637 Case Study of Baler, Aurora Province, Philippines, Master's Thesis, School of Urban and 638 Regional Planning, University of the Philippines, Unpublished results.

639 [58] Teknomo, K., Analytic Hierarchy Process (AHP) Tutorial. 2006. Accessed on November 22, 6402012 from http://people.revoledu.com/kardi/.

641 [59] Kafle, S.K., How Resilient are Our Communities? Continuity: The Magazine of the 642 Business Continuity Institute. Sep/ Oct 2010 Issue, 28-29. Accessed on November 22, 2012 from 643 http://www.forestrynepal.org/publications/article/4853.

644

645

646

647

648

649

650

651

652

653

654 

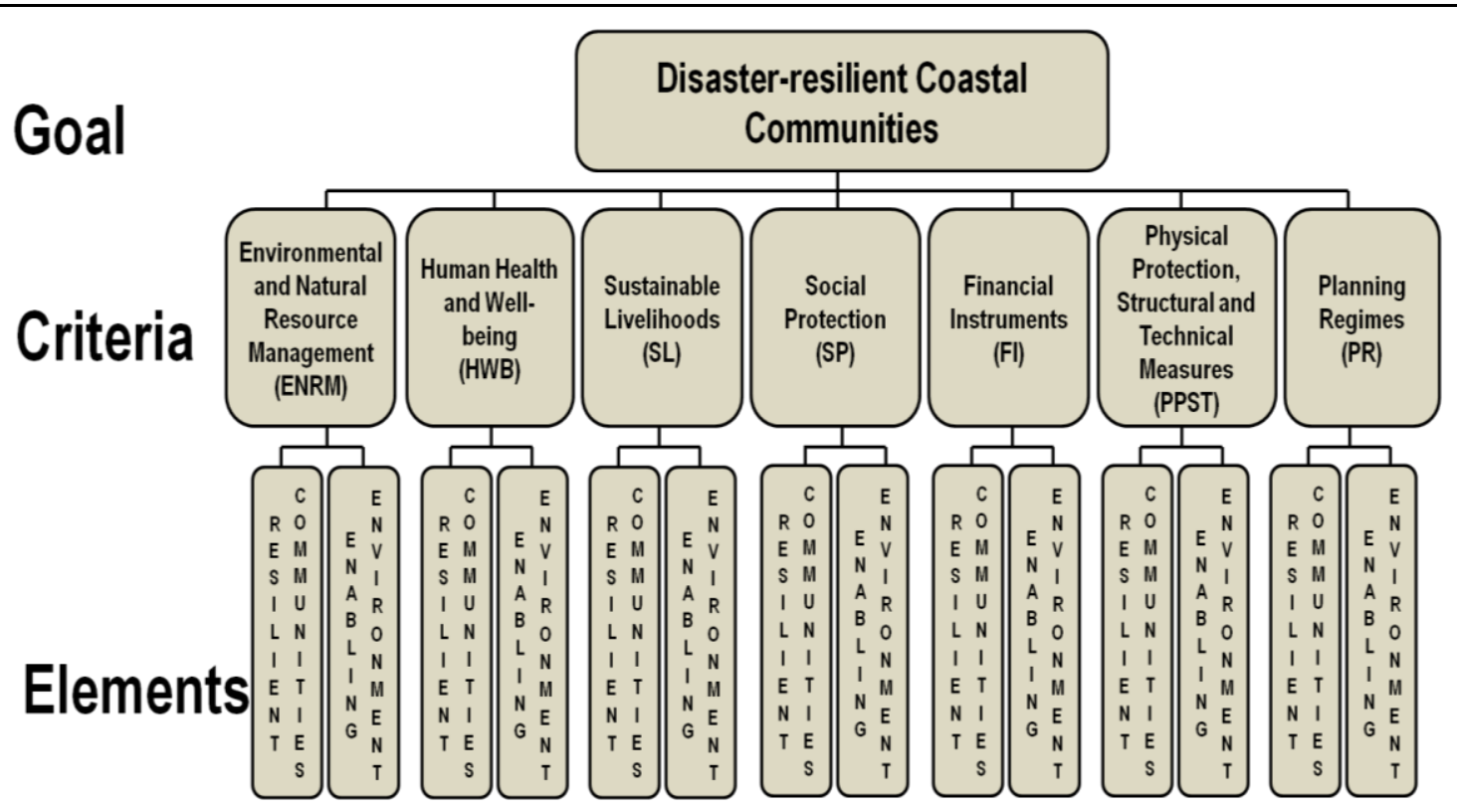

657

Figure 1. AHP model used in the process of prioritizing criteria for a disaster-resilient coastal 658 community

659
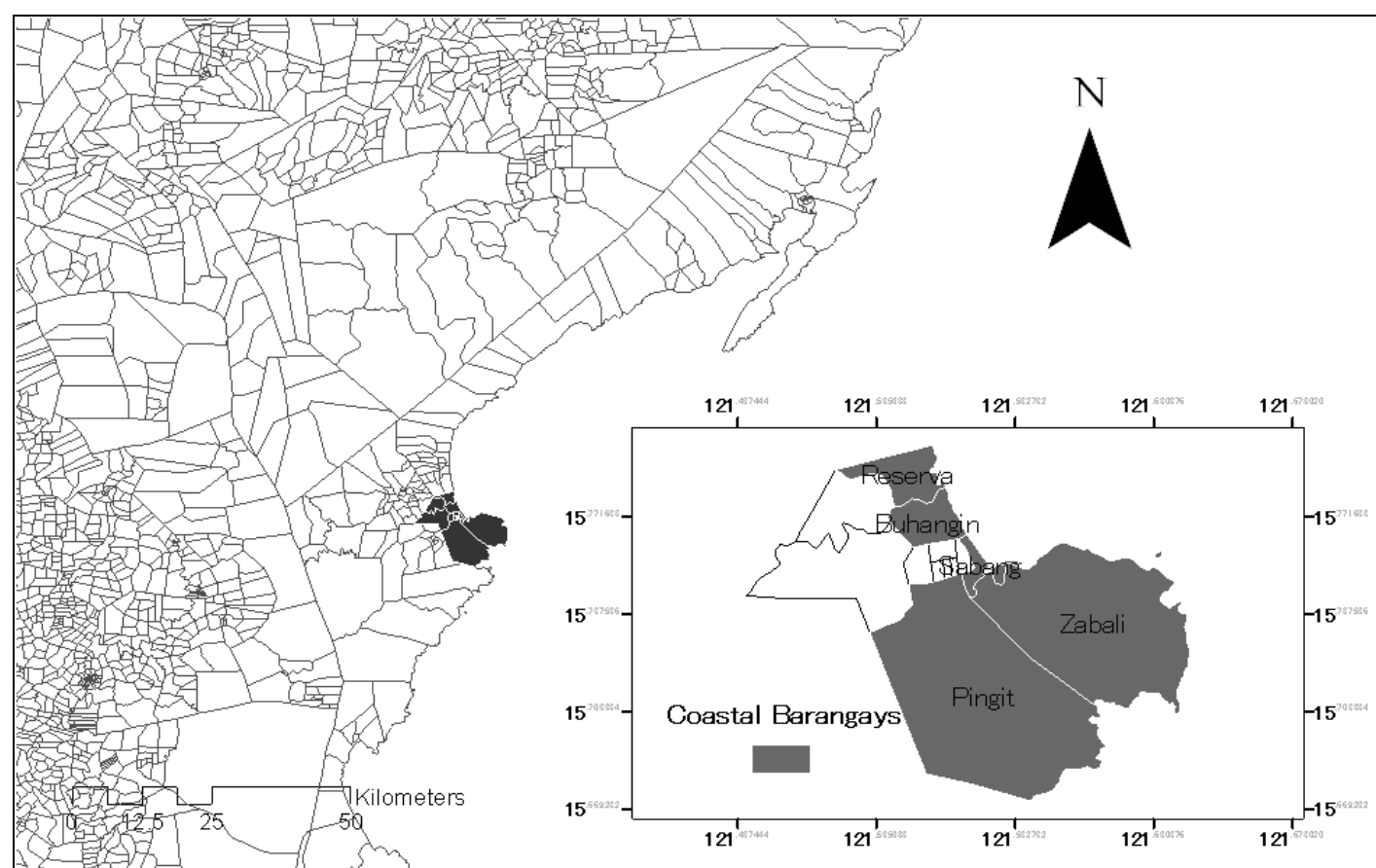

Figure 2. Map of the northeastern Philippines showing Baler, Aurora (inset map shows the five coastal communities) 


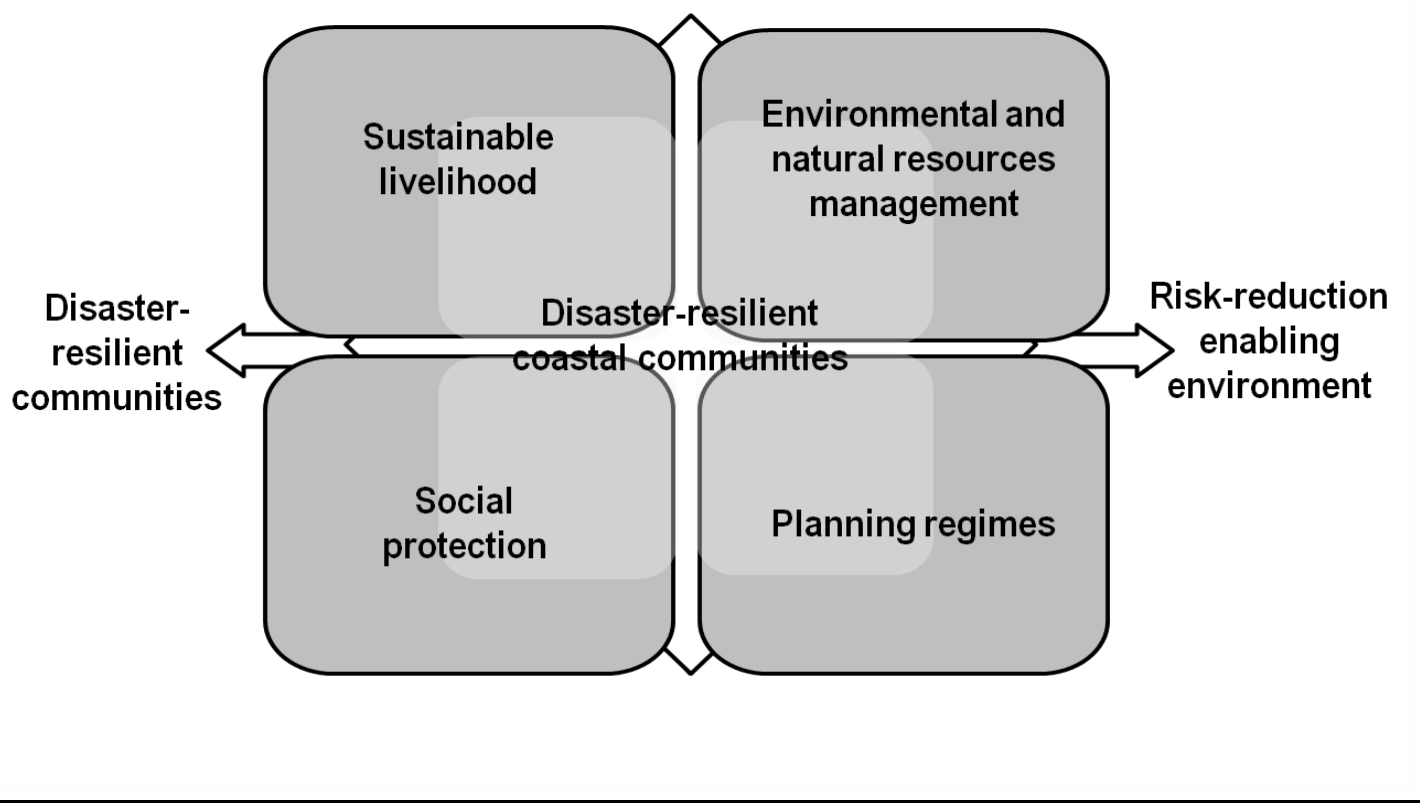

Figure 3. The AHP-designed coastal community disaster-resilience outcome framework for Baler, Aurora in the Philippines

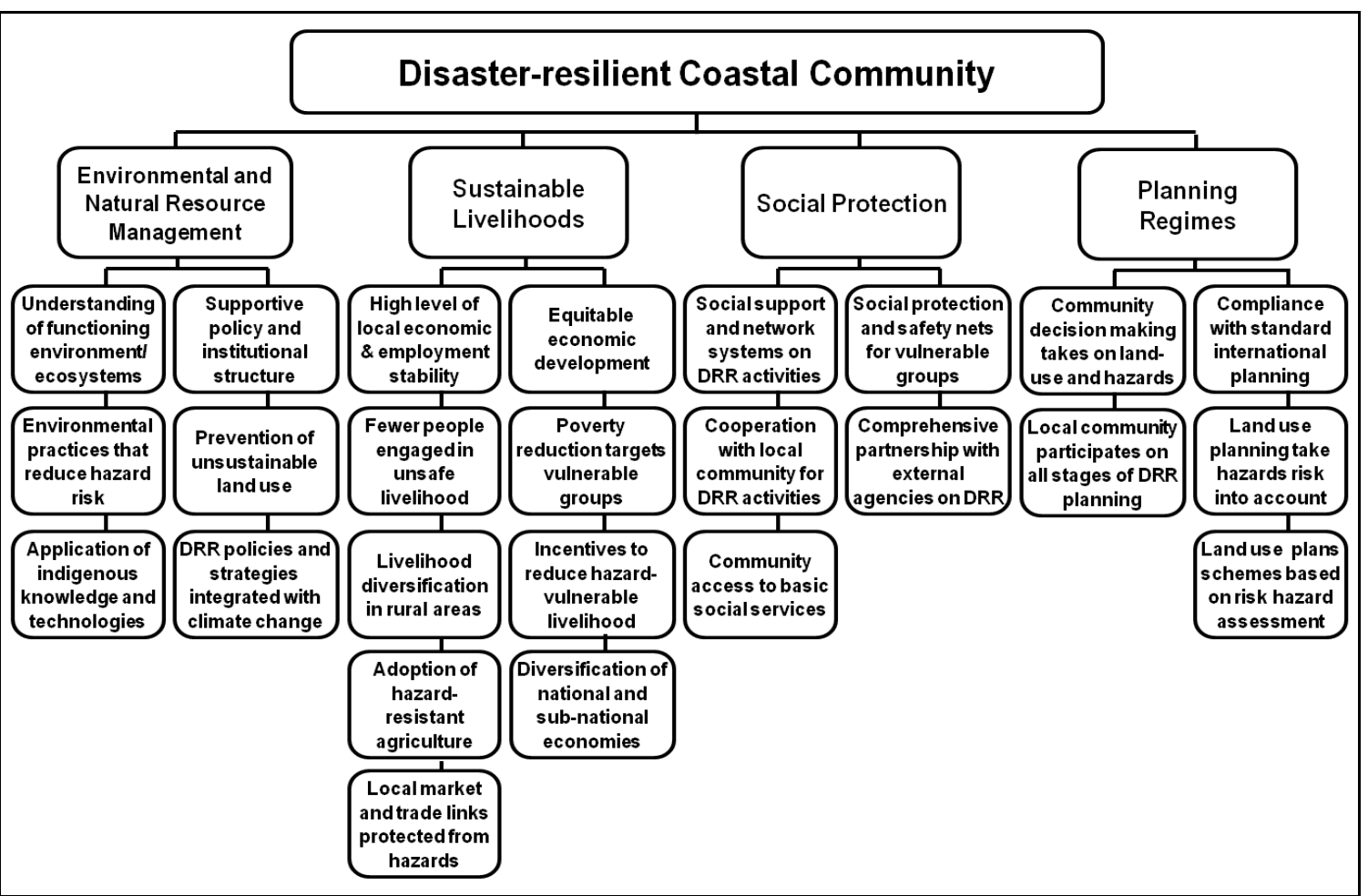

Figure 4. The criteria and elements for outcome components of a disaster-resilient coastal community from the AHP model 


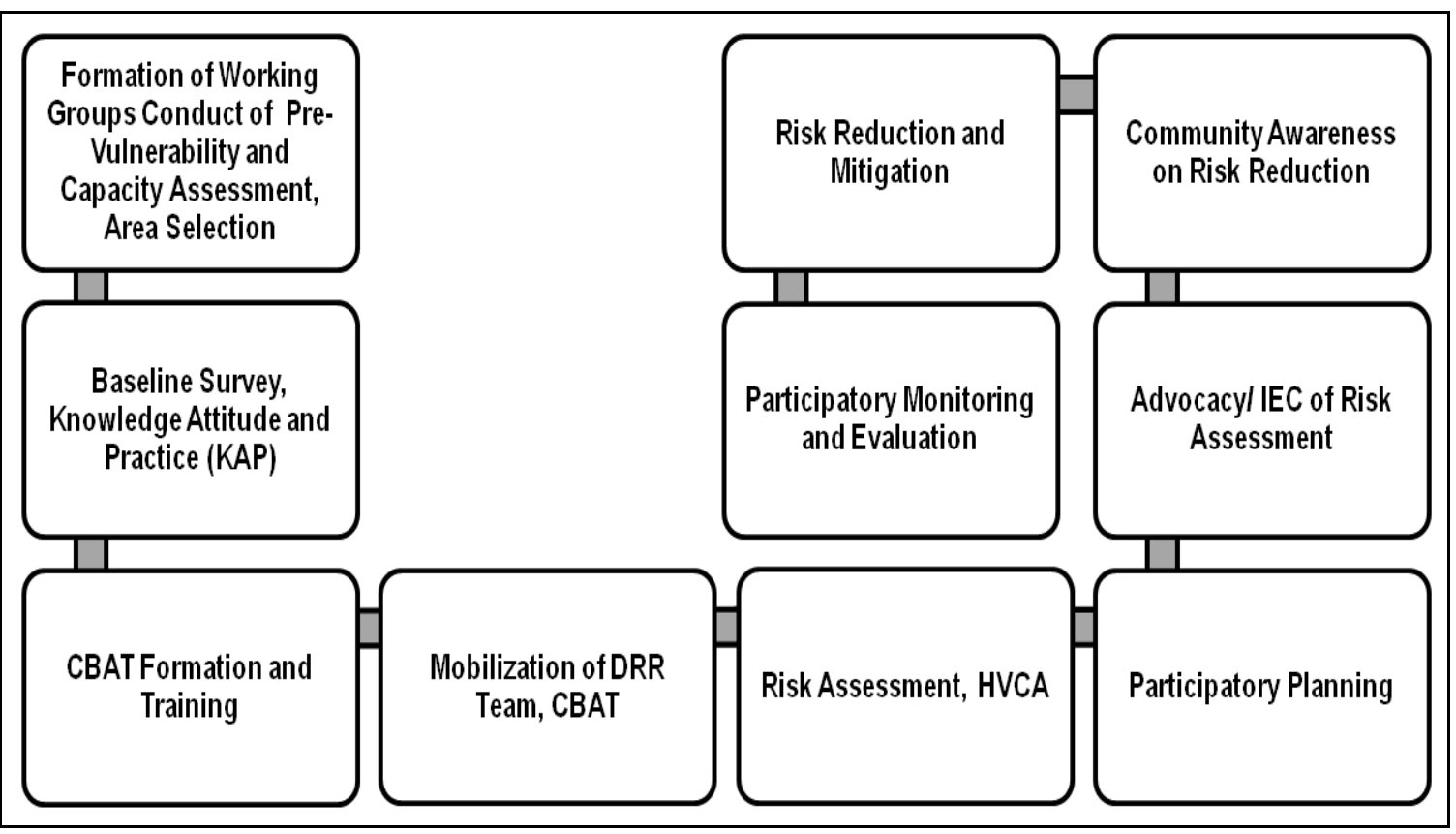

Figure 5. The ICBRR model used by the Canadian Red Cross and the Indonesian Red Cross Societies for building disaster-resilient organizations at the local level [59]

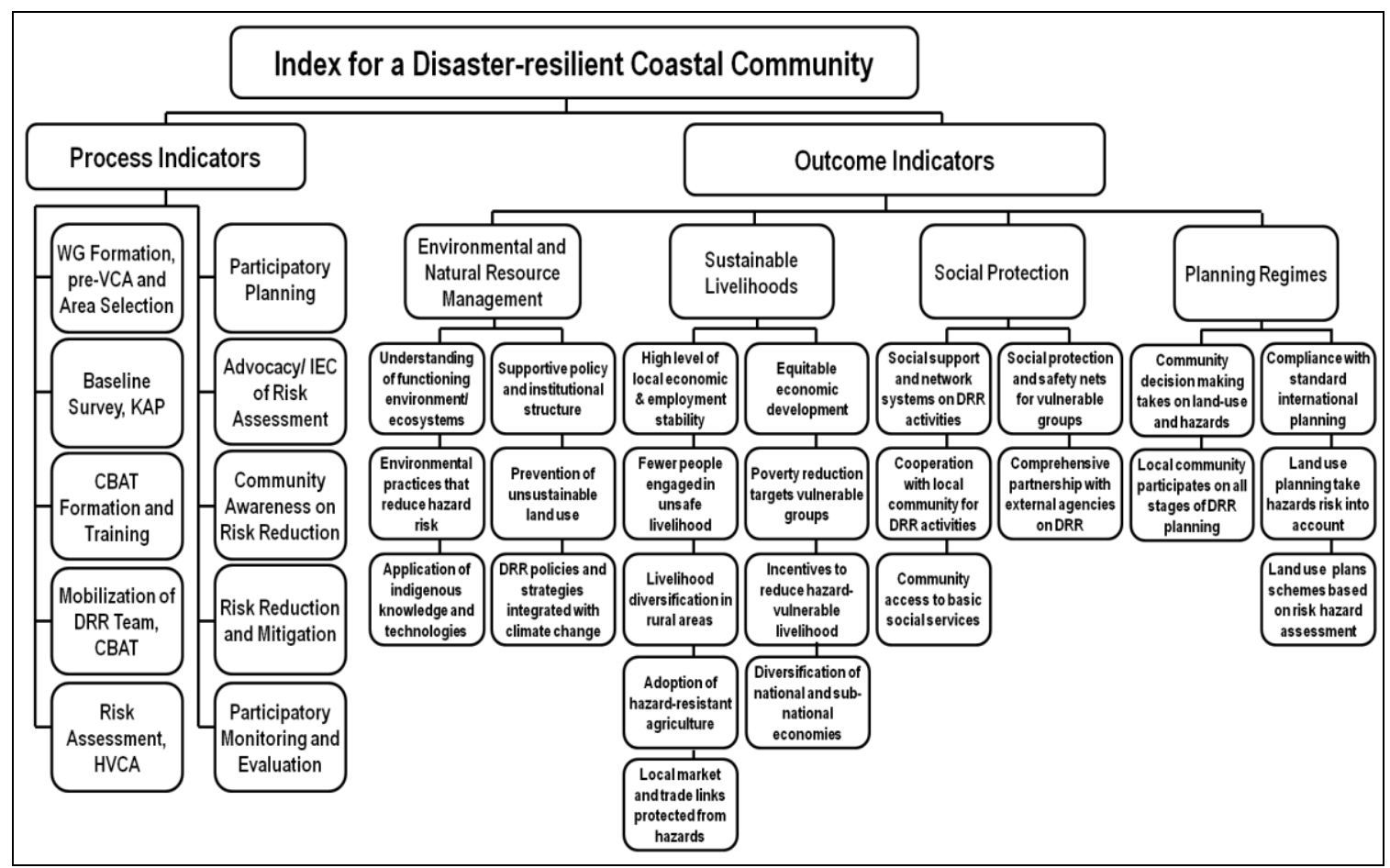

Figure 6. The process and outcome components of the composite index for a disaster-resilient coastal community 
Table 1. Components of risk-management and vulnerability-reduction systems [16,20]

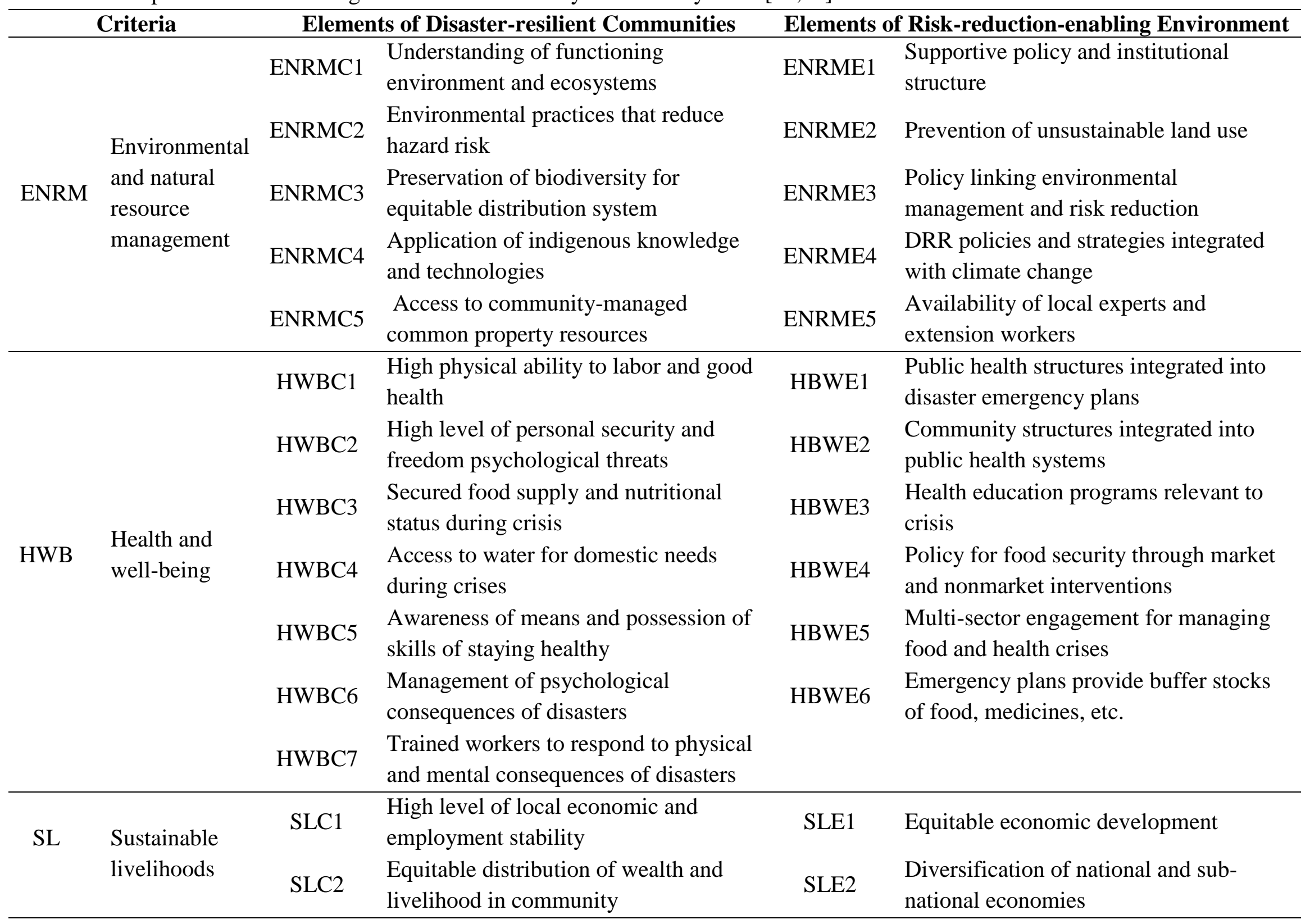




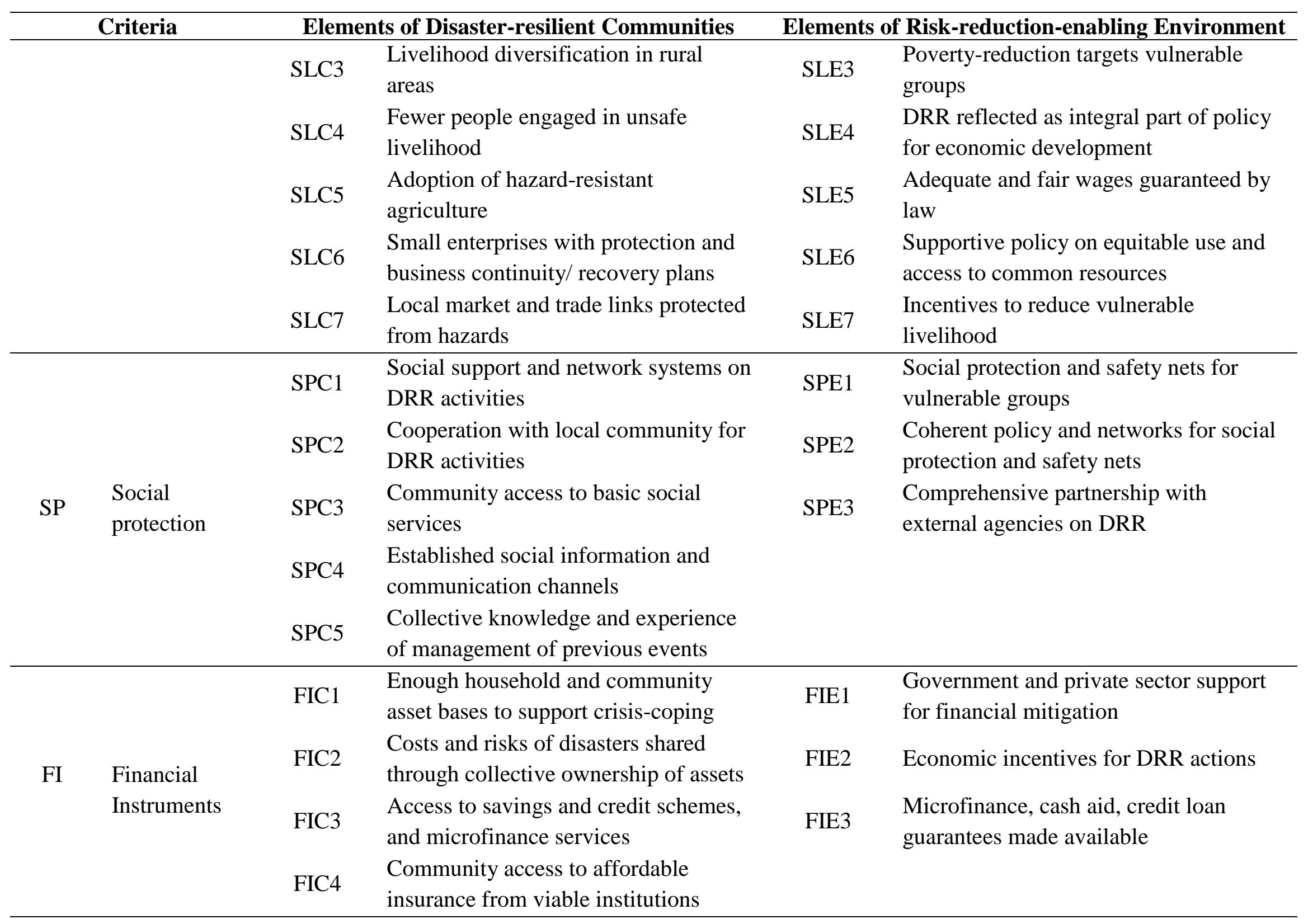




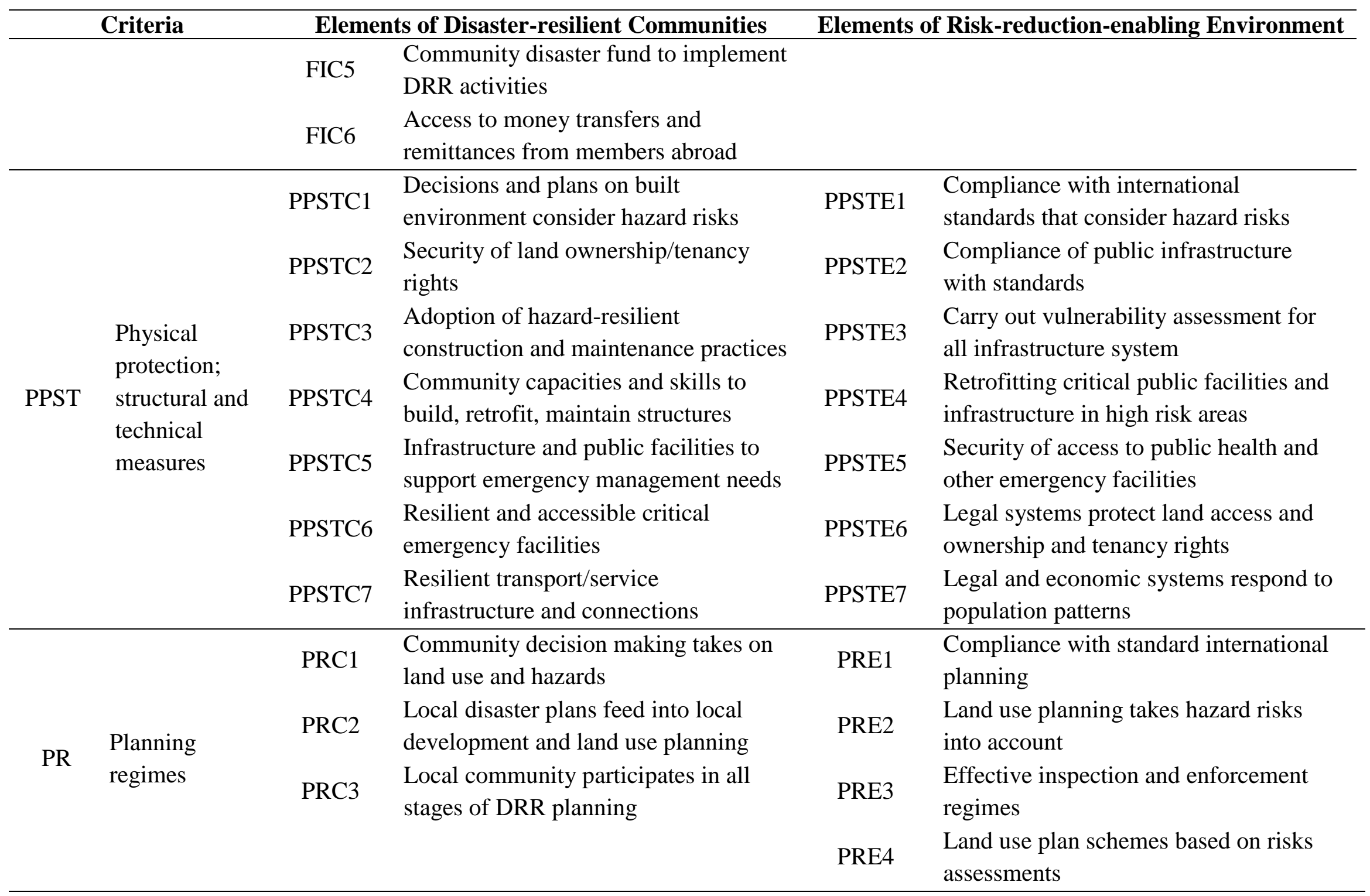


Table 2. Rating scale for judging preferences used for the pair-wise comparison of various criteria and attribute elements of a disaster-resilient coastal community

\begin{tabular}{ccl}
\hline Scale & Judgment of Preference & \multicolumn{1}{c}{ Description } \\
\hline 1 & Equally important & $\begin{array}{l}\text { Two factors contribute equally to the objective } \\
\text { Experience and judgment slightly favor one over } \\
\text { the other } \\
\text { Experience and judgment strongly favor one over } \\
\text { the other }\end{array}$ \\
7 & Soderately important & $\begin{array}{l}\text { Experience and judgment very strongly favor one } \\
\text { over the other, as demonstrated in practice } \\
\text { The evidence favoring one over the other is of the } \\
\text { highest possible validity }\end{array}$ \\
$2,4,6,8$ & $\begin{array}{l}\text { Extremely important } \\
\text { Intermediate preferences }\end{array}$ & When compromise is needed \\
\hline
\end{tabular}

Table 3. The order of the random index of consistency with a number of alternatives

\begin{tabular}{cccccccccccccccc}
$\mathbf{N}$ & 1 & 2 & 3 & 4 & 5 & 6 & 7 & 8 & 9 & 10 & 11 & 12 & 13 & 14 & 15 \\
$\mathbf{R I}$ & 0.00 & 0.00 & 0.58 & 0.90 & 1.12 & 1.24 & 1.32 & 1.41 & 1.45 & 1.49 & 1.51 & 1.48 & 1.56 & 1.57 & 1.59 \\
\hline
\end{tabular}

Table 4. Weights and ranks of various criteria of a disaster-resilient coastal community

\begin{tabular}{clcc}
\hline Codes & \multicolumn{1}{c}{ Criteria } & Weight & Rank \\
\hline \multirow{2}{*}{ ENRM } & $\begin{array}{l}\text { Environmental and natural resource management } \\
\text { (including natural capital and climate change } \\
\text { adaptation) }\end{array}$ & 1.90 & 1 \\
HWB & Health and well-being (including human capital) & 0.77 & 6 \\
SL & Sustainable livelihoods & 1.50 & 2 \\
SP & Social protection (including social capital) & 1.26 & 3 \\
FI & Financial instruments (including financial capital) & 0.81 & 5 \\
PPST & Physical protection; structural and technical & 0.57 & 7 \\
PR & measures (including physical capital) & 0.92 & 4 \\
& Planning regimes & $\lambda_{\max }=7.69 ; C I=0.11 ; C R=0.09$ \\
\hline
\end{tabular}


Table 5. Weights and ranks of various elements that characterized the selected criteria to produce a disaster-resilient coastal community

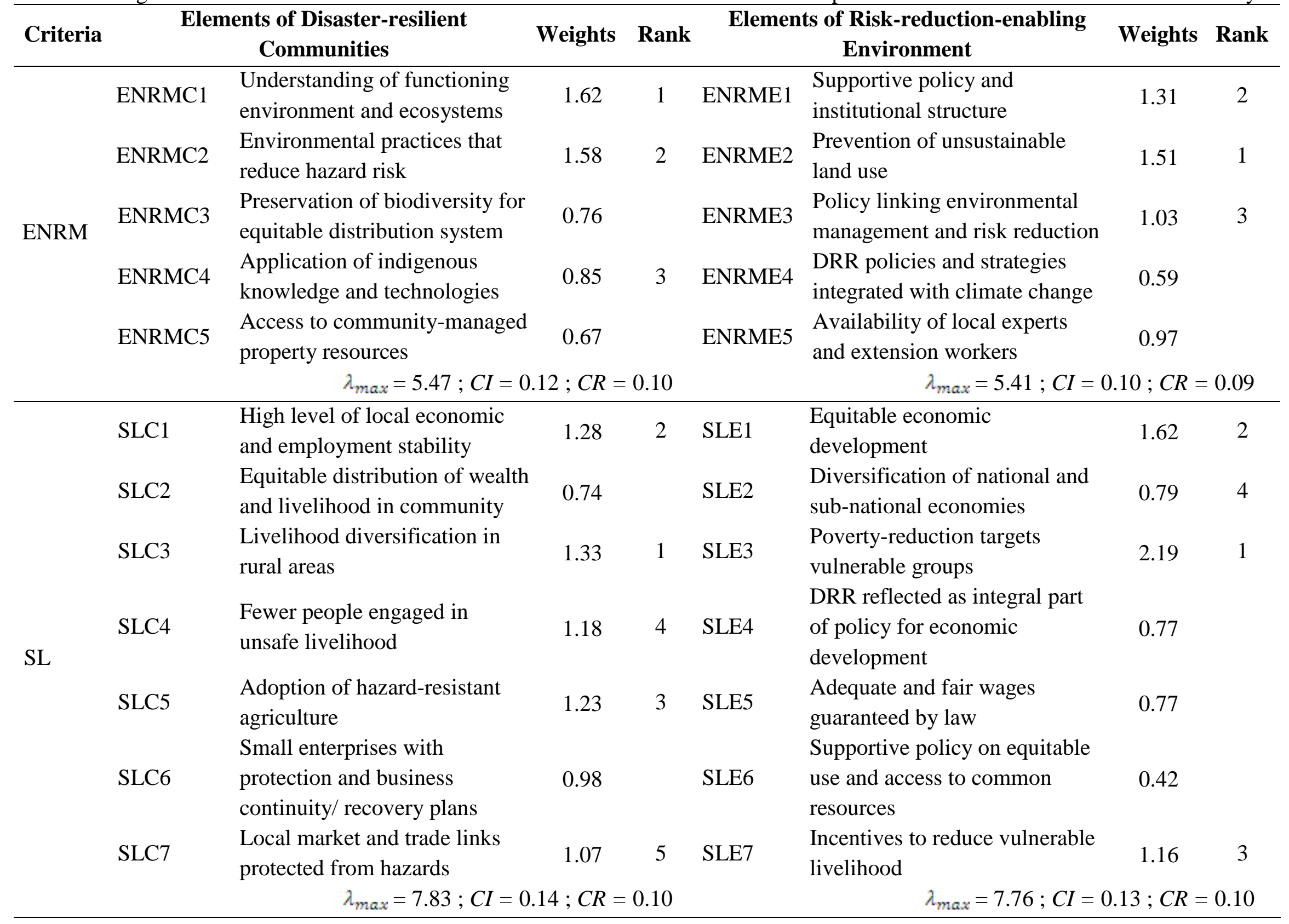




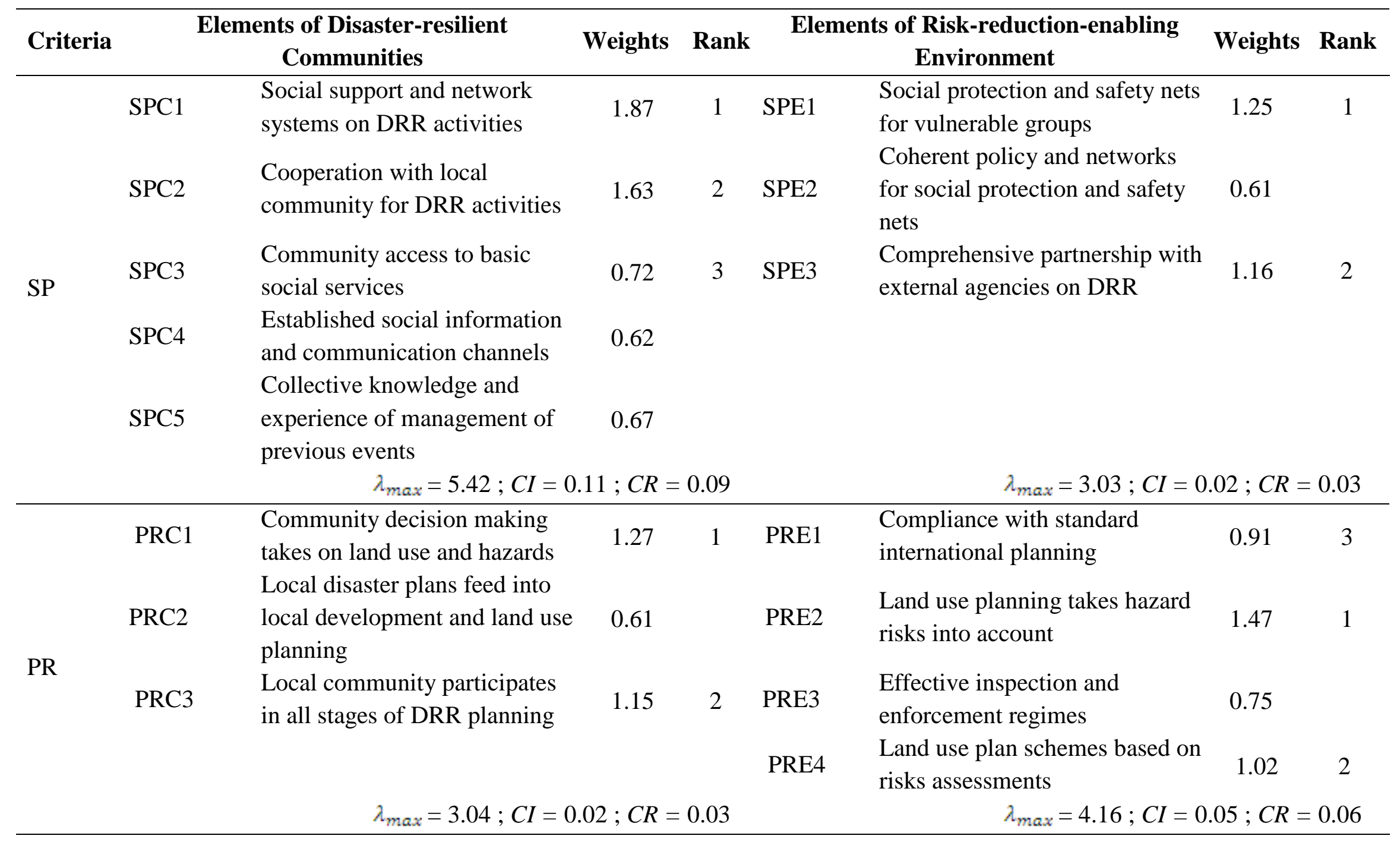


Table 6. Weights of criteria and element indicators that describe a disaster-resilient coastal community

\begin{tabular}{|c|c|c|c|c|c|c|c|}
\hline Criteria & $\begin{array}{l}\text { Normalized } \\
\text { Weights }\end{array}$ & Elem & $\begin{array}{l}\text { ents of Disaster-resilient } \\
\text { Communities }\end{array}$ & $\begin{array}{c}\text { Normalized } \\
\text { Weights }\end{array}$ & Elemen & $\begin{array}{l}\text { ts of Risk-reduction-enabling } \\
\text { Environment }\end{array}$ & $\begin{array}{c}\text { Normalized } \\
\text { Weights }\end{array}$ \\
\hline \multirow{3}{*}{ ENRM } & \multirow{3}{*}{0.40} & ENRMC1 & $\begin{array}{l}\text { Understanding of functioning } \\
\text { environment and ecosystems }\end{array}$ & 0.47 & ENRME1 & $\begin{array}{l}\text { Supportive policy and } \\
\text { institutional structure }\end{array}$ & 0.35 \\
\hline & & ENRMC2 & $\begin{array}{l}\text { Environmental practices that } \\
\text { reduce hazard risk }\end{array}$ & 0.44 & ENRME2 & $\begin{array}{l}\text { Prevention of unsustainable } \\
\text { land use }\end{array}$ & 0.44 \\
\hline & & ENRMC4 & $\begin{array}{l}\text { Application of indigenous } \\
\text { knowledge and technologies }\end{array}$ & 0.09 & ENRME3 & $\begin{array}{l}\text { Policy linking environmental } \\
\text { management and risk reduction }\end{array}$ & 0.21 \\
\hline \multirow{5}{*}{ SL } & \multirow{5}{*}{0.28} & SLC1 & $\begin{array}{l}\text { High level of local economic } \\
\text { and employment stability }\end{array}$ & 0.23 & SLE1 & $\begin{array}{l}\text { Equitable economic } \\
\text { development }\end{array}$ & 0.29 \\
\hline & & SLC3 & $\begin{array}{l}\text { Livelihood diversification in } \\
\text { rural areas }\end{array}$ & 0.25 & SLE2 & $\begin{array}{l}\text { Diversification of national and } \\
\text { sub-national economies }\end{array}$ & 0.09 \\
\hline & & SLC4 & $\begin{array}{l}\text { Fewer people engaged in } \\
\text { unsafe livelihood }\end{array}$ & 0.18 & SLE3 & $\begin{array}{l}\text { Poverty-reduction targets } \\
\text { vulnerable groups }\end{array}$ & 0.43 \\
\hline & & SLC5 & $\begin{array}{l}\text { Adoption of hazard-resistant } \\
\text { agriculture }\end{array}$ & 0.21 & SLE7 & $\begin{array}{l}\text { Incentives to reduce } \\
\text { vulnerable livelihood }\end{array}$ & 0.18 \\
\hline & & SLC7 & $\begin{array}{l}\text { Local market and trade links } \\
\text { protected from hazards }\end{array}$ & 0.14 & & & \\
\hline \multirow{3}{*}{ SP } & \multirow{3}{*}{0.21} & SPC1 & $\begin{array}{l}\text { Social support and network } \\
\text { systems on DRR activities }\end{array}$ & 0.53 & SPE1 & $\begin{array}{l}\text { Social protection and safety nets } \\
\text { for vulnerable groups }\end{array}$ & 0.54 \\
\hline & & SPC2 & $\begin{array}{l}\text { Cooperation with local } \\
\text { community for DRR activities }\end{array}$ & 0.43 & SPE3 & $\begin{array}{l}\text { Comprehensive partnership with } \\
\text { external agencies on DRR }\end{array}$ & 0.46 \\
\hline & & SPC3 & $\begin{array}{l}\text { Community access to basic } \\
\text { social services }\end{array}$ & 0.04 & & & \\
\hline \multirow{3}{*}{ PR } & \multirow{3}{*}{0.11} & PRC1 & $\begin{array}{l}\text { Community decision making } \\
\text { takes on land use and hazards }\end{array}$ & 0.55 & PRE1 & $\begin{array}{l}\text { Compliance with standard } \\
\text { international planning }\end{array}$ & 0.14 \\
\hline & & PRC3 & $\begin{array}{l}\text { Local community participates } \\
\text { in all stages of DRR planning }\end{array}$ & 0.45 & PRE2 & $\begin{array}{l}\text { Land use planning takes hazard } \\
\text { risks into account }\end{array}$ & 0.63 \\
\hline & & & & & PRE4 & $\begin{array}{l}\text { Land use plan schemes based on } \\
\text { risks assessments }\end{array}$ & 0.23 \\
\hline
\end{tabular}


Table 7. Six-level scale for ranking indicators as modified from Twigg's [16] five-level scale for ranking distinctive disaster risk-reduction interventions

\section{Levels Distinctive Disaster Risk-reduction Intervention}

Level 0

Absence of a clear and coherent activity/ activities in an overall disaster risk reduction program.

Level 1 Little awareness of the issue(s) or motivation to address them. Actions limited to crisis response.

Awareness of the issue(s) and willingness to address them. Capacity to act

Level 2 (knowledge and skills, human, material and other resources) remains limited. Interventions tend to be one-off, piecemeal and short-term.

Level 3 Development and implementation of solutions. Capacity to act is improved and substantial. Interventions are more numerous and long-term.

Coherence and integration. Interventions are extensive, covering all main

Level 4 aspects of the problem, and they are linked within a coherent long-term strategy.

A "culture of safety" exists among all stakeholders, where Disaster Risk

Level 5 Reduction (DRR) is embedded in all relevant policy, planning, practice, attitudes and behavior. 